\title{
Postponed surgery of an acute aortic dissection (type A) in a Jehovah's Witness with significant hemostatic disorders
}

\author{
Andrzej Biskupski, Szymon Waligórski, Krzysztof Mokrzycki, Mirosław Brykczyński \\ Cardiac Surgery Department, Pomeranian Medical University, Szczecin, Poland
}

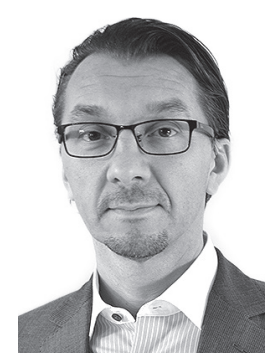

Kardiochirurgia i Torakochirurgia Polska 2016; 13 (3): 251-253

\begin{abstract}
In this case report, we present the treatment of an acute type A aortic dissection in a Jehovah's Witness patient. In accordance with the will of the patient, blood products were not used. Additionally, the patient had significant hemostatic disorders due to the use of antiplatelet drugs.

Key words: aortic dissection, hemostatic disorder.
\end{abstract}

\section{Introduction}

Jehovah's Witnesses are members of a religious association. They do not accept transfusions of blood or blood components. Acute aortic dissection surgery usually requires the transfusion of blood or blood components. The reported case involved a unique approach to the cardiac patient. The dilemma involved two factors: on the one hand, we had to perform surgery for an acute aortic dissection, while, on the other, the patient had a significant hemostatic disorder due to platelet dysfunction and did not express consent for the transfusion of blood or its components.

\section{Case report}

A 76-year-old man was urgently transferred to our institution from a local hospital with suspected acute aortic dissection. After experiencing severe chest pain, he called for an ambulance. The ambulance paramedics administered a loading dose of aspirin (300 mg) and clopidogrel (600 mg) for suspected acute coronary syndrome. The patient was then taken to the district hospital, where he was diagnosed with acute aortic dissection (type A). On admission to the cardiac surgery department, the patient's condition was stable. Transesophageal echocardiography (TEE, Fig. 1) was performed, confirming the presence of dissection at the aortic root level. The ascending aorta was enlarged to $5.7 \mathrm{~cm}$. There was moderate aortic valve regurgitation. Other valves showed no significant pathological changes. There was a trace of pericardial fluid. The dimension of the aortic arch was $3 \mathrm{~cm}$. Left ventricular ejection fraction

\section{Streszczenie}

Przedstawiono opis przypadku ostrego rozwarstwienia aorty typu A u pacjenta - świadka Jehowy. Zgodnie z wolą pacjenta nie podawano krwi i środków krwiopochodnych. Dodatkowo pacjent miał znaczące zaburzenia krzepnięcia krwi z powodu przyjęcia leków przeciwpłytkowych.

Słowa kluczowe: rozwarstwienie aorty, zaburzenia krzepnięcia.

was good (EF 55\%). Blood impedance platelet aggregometry measured with a Multiplate analyzer (Dynabyte) demonstrated impaired platelet function (ASP test: $5 \mathrm{U}$, norm: 75-136; ADP test: $8 \mathrm{U}$, norm: 53-122). Laboratory tests: hemoglobin ( $\mathrm{Hb}) 8.3 \mathrm{mmol} / \mathrm{l}$, hematocrit (HTC) 40\%, red blood cell count (RBC) $4.53 \mathrm{~T} / \mathrm{l}$, platelet (PLT) $141 \mathrm{G} / \mathrm{l}$; activated prtial thromboplastin time (APTT) $41.7 \mathrm{~s}$ (norm: 22-35), international normalized ratio (INR) 1.58 (norm: 0.9-1.15), antithrombin III 40\% (norm: 80-120\%), creatinine $0.73 \mathrm{mg} / \mathrm{dl}$, glomerular filtration rate (GFR) $90 \mathrm{ml} / \mathrm{min} / 1.73 \mathrm{~m}^{2}$.

The patient was informed about the natural course of the disease as well as the risks and benefits associated with surgical treatment. The risk of surgery according to

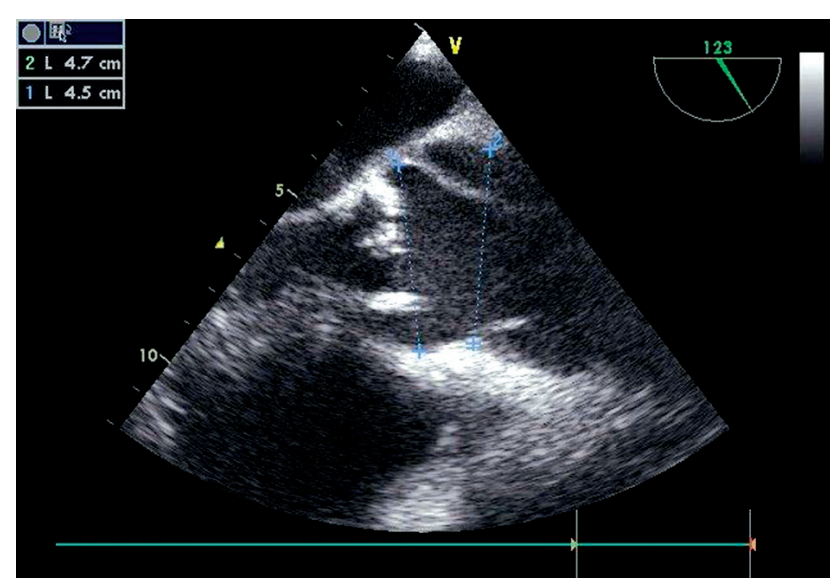

Fig. 1. Transesophageal echocardiography (TEE) confirmed dissection at the ascending aorta

Address for correspondence: Dr. Andrzej Biskupski, Cardiac Surgery Department, Pomeranian Medical University, Al. Powst. Wlkp. 72, 70-111 Szczecin, Poland, phone: +48 606345 943, fax: +48 9146613 93, e-mail: a.biskupski@vp.pl

Received: 26.08.2015, accepted: 7.09.2015. 
the logistic EuroSCORE was 35\%. The patient's comorbidities included coronary artery disease, type 2 diabetes, and rheumatoid arthritis. His prior surgical history also included abdominal aortic aneurysm surgery. The patient was also informed about the very high risk of postoperative bleeding in the presence of coagulation disorders. However, he still refused to undergo transfusion of blood or blood products even in case of life-threatening complications. Under these circumstances, we decided to proceed with the surgical treatment of the patient, but the operation was postponed in order to correct the coagulation disorders. The situation was described in the patient's records, and written consent was obtained from the patient.

While waiting for the postponed surgery, the patient did not complain of pain, and his condition remained stable. We did not observe any change in the aortic dissection on echocardiography. The patient received iron supplementation, folic acid, and erythropoietin. On the tenth day of hospitalization, after demonstrating normal platelet function with platelet aggregometry, with INR decreased to 1.28 and antithrombin III increased to $65 \%$, the patient was operated on.

Anesthesia was performed according to standard operating procedures. Cannulation for cardiopulmonary bypass was performed through the femoral vessels. Heparin was administered intravenously at a dose of 37500 IU (400 IU/ $\mathrm{kg}$ ). The efficacy of heparinization was controlled by the measurement of activated clotting time - ACT (Hepcon HMS, Medtronic, Minneapolis, MN). Subsequently, cardiopulmonary circulation was established, and the chest was opened through sternotomy. There were inflammatory adhesions of the heart with the pericardium, which were easily released. A vent suction line was introduced into the left ventricle through the right upper pulmonary vein. The aorta was clamped at the base of the aortic arch. After the aorta was opened, cold crystalloid cardioplegia was administered into the coronary ostia. The proximal and distal parts of the aorta were reinforced with Teflon strips, and repair was performed using a vascular prosthesis (Vascutec $30 \mathrm{~mm}$ ). The patient's temperature was maintained at a normal level during the operation. The pump was primed with $2000 \mathrm{ml}$ of crystalloid solution. The lowest level of hemoglobin during cardiopulmonary bypass was $4.5 \mathrm{mmol} / \mathrm{l}$. Before the end of cardiopulmonary bypass, hemofiltration was performed, and $2000 \mathrm{ml}$ of filtrate was withdrawn. The aorta cross-clamping time was 84 minutes, and the duration of reperfusion was 52 minutes. In total, extracorporeal circulation lasted 175 minutes. Heparin activity was reversed by the administration of protamine sulfate $-375 \mathrm{mg}$ (a dose corresponding to the amount of heparin in the ratio of $1 \mathrm{mg}: 100 \mathrm{IU}$ ). The sternotomy wound was then closed without suturing the pericardium; two drains (32 Fr) were left in the pericardium. During the operation, tranexamic acid was administered (2 g as an intravenous infusion and $500 \mathrm{mg}$ into the extracorporeal circulation circuit with priming). Postoperative drainage was $220 \mathrm{ml}$, and the drains were removed on the second day after the operation. In this situation there was no need for auto-transfusion of shed blood.
On the first postoperative day, the patient was conscious and had no neurological deficits. He was extubated 13 hours after the operation. Laboratory tests on the first postoperative day showed: Hb $6.8 \mathrm{mmol} / \mathrm{l}$, HTC 35\%, RBC $3.96 \mathrm{~T} / \mathrm{l}, \mathrm{PLT} 287 \mathrm{G} / \mathrm{l}$. The lowest value of blood cell counts was observed on the $7^{\text {th }}$ day after the surgery $(\mathrm{Hb}$ $4.3 \mathrm{mmol} / \mathrm{l}$, HTC 24\%, RBC $2.5 \mathrm{~T} / \mathrm{l}$, PLT $244 \mathrm{G} / \mathrm{l})$. The patient received additional doses of erythropoietin (8000 IU on the $5^{\text {th }}$ postoperative day and 4000 IU each subsequent day) in addition to folic acid and iron supplementation.

The postoperative course was complicated by cardiovascular instability requiring inotropic medication (discontinued on the $5^{\text {th }}$ day after the surgery). On the first postoperative day, acute renal failure was diagnosed, necessitating the use of continuous renal replacement therapy, which was completed 7 days after the surgery, after satisfactory urine output was obtained. Because of respiratory failure, the patient was intubated again on the third postoperative day (60 hours after the operation) and remained on a ventilator until the seventh postoperative day. Twenty days after the surgery, he was transferred to the district hospital. There, during the second month after the operation ( $58^{\text {th }}$ postoperative day) he died from respiratory failure due to severe pneumonia.

\section{Discussion}

The proportion of patients not expressing consent to a blood transfusion after cardiac surgery is minimal. According to the literature, it is less than $1 \%$. If the surgery is planned, there is ample time to prepare such a patient. Very rarely do we have to deal with urgent surgery. Only a few cases of surgical treatment for acute aortic dissection in Jehovah's Witnesses have been described in the medical literature. In addition, there have been no cases in which urgent surgery was needed for an acute aortic dissection in a Jehovah's Witness with completely blocked platelet function who would not express consent for a blood transfusion. We believe that this is the first description of such a case.

The available case reports of acute aortic dissection in Jehovah's Witnesses show that such an operation can be safely performed without the need for a transfusion of blood or blood products. However, in the presence of significant coagulation disorders that cannot be leveled out immediately and in the absence of consent for blood transfusion, we believe that surgery should be postponed until optimal clotting is achieved. The patient needs to be informed about the enormous risk of operating without blood transfusions and about the risk of postponing acute aortic dissection surgery. According to the International Registry of Acute Aortic Dissection, the mortality rate for acute aortic dissection without surgical treatment exceeds $60 \%$, while the surgical mortality rate in such cases is approximately $25 \%$ [1].

Normal platelet function should return 5-7 days after the discontinuation of antiplatelet drugs. We recommend that the assessment of platelet function be done by aggregometry. Furthermore, the coagulation system should 
be assessed with thromboelastometry. During the waiting period for the restoration of normal hemostasis, iron preparations, vitamin $B_{12}$, folic acid, and erythropoietin may be administered [2-5]. It is mandatory to control and normalize the patient's blood pressure.

After obtaining optimal results, blood counts, and clotting, the decision to perform the operation should be made. The operation should be performed in normothermia since hypothermia disturbs hemostasis. Hemodilution during the cardiopulmonary bypass is not deleterious as it protects the formed elements of blood. Before the end of cardiopulmonary bypass, hemofiltration may be used in order to bring the hematocrit back to the baseline level.

Intraoperatively, tranexamic acid is administered in a dose of 25-35 mg/kg [6]. Desmopressin can also be administered, improving the function of platelets and the endothelium [3, 7]. Moreover, if the patients are willing, they receive cryoprecipitate and recombinant coagulation factor VIla at a dose of $90 \mathrm{mg} / \mathrm{kg}$ i.v. near the end of the cardiopulmonary bypass [8].

The surgical approach requires special attention to hemostasis from the very beginning of the operation. We recommend introducing cardiopulmonary circulation cannulas to the femoral vessels under the control of transesophageal echocardiography (TEE) to assess their proper position. Starting cardiopulmonary bypass before sternotomy is helpful. It allows blood to return to the circuit in case of bleeding and facilitates the dissection of adhesions. In our case, we tried to minimize the extent of the operation by using a simple vascular prosthesis for the ascending aorta and to improve hemostasis by using felt strips in order to secure the anastomosis. In addition, fibrin glue may be used to seal the anastomosis provided that the patient does not object to it. After the operation, blood pressure should remain under $100 \mathrm{~mm} \mathrm{Hg}$ to minimize post-operative bleeding. The blood left in the reservoir, oxygenator, and drains of the cardiopulmonary circulation set may be used for autologous retransfusion with the help of a cell saving device (Cell Saver system), to which our patient did not object. Postoperative erythropoietin use rates depend on the severity of anemia. We also recommended supplements of iron and folic acid.
The strategy adopted in this particular case gave the patient an opportunity to survive the operation and the postoperative period. Unfortunately, the patient died due to severe pneumonia, which was not directly related to postoperative anemia.

This paper was presented during the $7^{\text {th }}$ Congress of the Polish Society of Cardio-Thoracic Surgeons in Warsaw and during the $16^{\text {th }}$ Gdansk Cardiac Surgery Meeting in 2014.

\section{Disclosure}

Authors report no conflict of interest.

\section{References}

1. Trimarchi S, Nienaber CA, Rampoldi V, Myrmel T, Suzuki T, Mehta RH, Bossone E, Cooper JV, Smith DE, Menicanti L, Frigiola A, Oh JK, Deeb MG, Isselbacher EM, Eagle KA; International Registry of Acute Aortic Dissection Investigators. Contemporary results of surgery in acute type $A$ aortic dissection: the International Registry of Acute Aortic Dissection experience. J Thorac Cardiovasc Surg 2005; 129: 112-122.

2. Emmert MY, Salzberg SP, Theusinger OM, Felix C, Plass A, Hoerstrup SP, Falk V, Gruenenfelder J. How good patient blood management leads to excellent outcomes in Jehovah's witness patients undergoing cardiac surgery. Interact Cardiovasc Thorac Surg 2011; 12: 183-188.

3. Jassar AS, Ford PA, Haber HL, Isidro A, Swain JD, Bavaria JE, Bridges CR. Cardiac surgery in Jehovah's Witness patients: ten-year experience. Ann Thorac Surg 2012; 93: 19-25.

4. Loubser PG, Stoltz SM, Schmoker JD, Bonifacio F, Battle RW, Marcus S, Krumholz CF, Moskowitz DM, Shander A, Lemmer JH Jr. Blood conservation strategies in Jehovah's Witness patients undergoing complex aortic surgery: a report of three cases. J Cardiothorac Vasc Anesth 2003; 17: 528-535.

5. Vaislic CD, Dalibon N, Ponzio O, Ba M, Jugan E, Lagneau F, Abbas P, Olliver Y, Gaillard D, Baget F, Sportiche M, Chedid A, Chaoul G, Maribas P, Dupuy C, Robine B, Kasanin N, Michon H, Ruat JM, Habis M, Bouharaoua T. Outcomes in cardiac surgery in 500 consecutive Jehovah's Witness patients: 21 year experience. J Cardiothorac Surg 2012; 7: 95.

6. Biskupski A, Waligórski S, Kowalik B, Żych A, Brykczyński M. Tranexamic acid in emergency coronary surgery. Time for routine use? Kardiochir Torakochir Pol 2012; 9: 170-174.

7. Papalexopoulou N, Attia RQ, Bapat VN. Successful surgical repair of acute type A aortic dissection without the use of blood products. Ann R Coll Surg Engl 2013; 95: 127-129.

8. Ballen J, Raabe M, Muirhead B. Aortic dissection and hypothermic arrest in a Jehovah's Witness patient: a case for recombinant factor VIla? Can J Anesth 2006; 53: 353-356. 